Н.В. Башкірова,

кандидат біологічних наук

Національний університет

біоресурсів

і природокористування України

\title{
А.О. Глибовець
}

Український інститут експертизи сортів рослин

\section{Оиінка нових самофертильних селекціиних зразків люцерни nocibroï (Medicago sativa L.)}

Урожайність насіння сучасних сортів цінної кормової культури лючерни посівної є досить низькою - 0,2-0,3 m/га. Причина цього - недостатній рівень перехресного запилення через відсутність комах - запилювачів. У цих умовах вищу насінну продуктивність мають рослини, схильні до самозапилення. Наведено результати вивчення 26 нових самофертильних зразків люцерни посівної, створених протягом двадияти років. Показано, що п'ятнадиять зразків за врожайністю насіння перевищують сорт-стандарт Ярославна. Тільки чотири зразки мали урожайність зеленої маси нижчу, від стандарту. Вміст сухої речовини у всіх зразків був високий - від 22,1 до 25,5\%. Одержані результати дали змогу виділити в розсаднику попереднього сортовипробування цінні зразки з високим рівнем самофертильності, урожайністю насіння 0,24-0,29 m/га, зеленої маси за три укоси - 63,2-67,7 m/га, високим умістом сухої речовини, які будуть використані у подальшому селекційному процесі.

\section{Ключові слова:}

люцерна посівна, самофертильність, урожайність насіння люцерни, зелена маса люцерни, вміст сухої речовини.

\section{Постановка проблеми.} Люцерна - найдавніша кормова культура, яку вирощували ще 5 тис. років тому в країнах Сходу та Африки. Їі насіння, як і насіння еспарцету та пшениці, знайдено в пірамідах Єгипту. За свідченнями багатьох європейських і вітчизняних учених люцерну вирощували задовго до нової ери в Китаї, Індії, Персії, Єгипті та інших країнах.

У групі багаторічних бобових трав люцерна - лідер за продуктивністю, вмістом білка, збалансованого за амінокислотним складом. Із зеленої маси люцерни готують високоякісні корми: сінаж, сіно, білковопротеїновий концентрат, сінне та трав'яне борошно, брикети, гранули. Травостої іiї можна випасати. Хімічний склад зеленої маси люцерни та суха речовина (фаза бутонізації) містять 20\% протеїну, 3,0\% жиру, майже всі макро- та мікроелементи, біологічно активні речовини [1].

Крім кормової цінності, люцерна також $\epsilon$ дуже цінним попередником у системі сівозмін для більшості сільськогосподарських культур. Здатність її вступати в симбіоз 3 бульбочковими бактеріями дає можливість після збирання разом з кореневими і пожнивними рештками залишати в ґрунті від 50 до 200-300 кг/га фіксованого 3 повітря азоту. Кожний одержаний 1 ц сіна залишає у ґрунті 1-1,5 кг азоту. Отже, як попередник вона сприяє підвищенню родючості ґрунту, покращуючи його фізико-хімічні та механічні властивості [2].

Нові сорти, створені у науково-дослідних установах, мусять бути стійкими проти несприятливих ґрунтово-кліматичних умов, хвороб і шкідників, добре реагувати на внесення добрив та зрошення, спроможними давати високі врожаї зеленої маси, мати стабільну насінну продуктивність. Розширення ареалу посівів люцерни та різноманітні напрями використання ії врожаю (у Європі останнім часом люцерна стає цінною салатною овочевою та лікарською культурою), пророщене насіння $\epsilon$ складовою більшості біологічно активних добавок (БАД), зумовлюють необхідність зростання урожайності насіння. Як вважають учені багатьох країн, основною причиною низької врожайності насіння люцерни $є$ недостатній рівень перехресного запилення унаслідок катастрофічного зниження чисельності комах-запилювачів [3, 4].

У середині XX ст. вчені наголошували на негативних наслідках достатньо непродуманої діяльності людства з приводу 
Оцінка нових самофертильних селекційних зразків люцерни посівної (Medicago sativa L.)

застосування великої кількості хімічних засобів боротьби зі шкідниками й хворобами сільськогосподарських культур, використання для їх внесення сільськогосподарської авіації, розорювання цілинних земель, які заселялися представниками диких видів бджолиних, дуже цінних комах-запилювачів багатьох родин, зокрема родини Fabaceae. Чисельність таких корисних комах у другій половині XX ст. катастрофічно зменшилась. Рівень перехресного запилення у ряді країн Європи становив 15-20\%, що призвело до зниження врожайності багатьох плодових, овочевих і кормових культур, які $\epsilon$ перехреснозапильними. Достатньо сказати, що за біологічної врожайності насіння рослин люцерни посівної 3,0-3,2 т/га, фактична урожайність у більшості країн становить 0,25-0,30 т/га.

Рослини люцерни посівної, як і інших представників родини, протягом тривалого процесу еволюції у боротьбі за комах-запилювачів набули специфічної будови квітки. Оцвітина складається 3 п'яти пелюсток, найбільша має назву вітрила (парусу), дві бічні називаються веслами, а дві останні зрослись у човник, у якому знаходиться маточка та десять тичинок [5].

У люцерни човник квітки закритий, і для проходження процесів запилення та запліднення необхідно його розкриття (триппінг), при якому тичинково-маточкова колонка, звільняючись із човника, вдаряється по комасі, кутикула приймочки маточки руйнується, пилок з комахи попадає на маточку й починає проростати. Квітки утворюють велику кількість нектару, нектарники розташовані в глибині квітки, біля чашечки.
Запилюються такі квітки тільки джмелями або представниками диких видів бджіл, які можуть ефективно розкривати квітки, дістаючи нектар і пилок. Медоносні бджоли висмоктують нектар, розміщуючи хоботок між парусом та веслами, квітка при цьому залишається закритою.

Багато представників родини Fabaceae за довгий період відсутності достатньої кількості комах-запилювачів перейшли до самозапилення, це соя, горох, який в генетичному центрі походження дотепер $\epsilon$ перехреснозапильним, квасоля, багато однорічних видів люцерни.

Тому базуючись на законі M.I. Вавилова про гомологічні ряди спадкової мінливості, вчені Італії, Франції, США, Угорщини, колишнього СРСР у 70-ті роки XX століття почали працювати над створенням самозапильних сортів люцерни посівної [6-9]. Рослини таких сортів не втрачають здатності до перехресного запилення, а в умовах недостатнього рівня чисельності комах-запилювачів зав'язують насіння від самозапилення при автотриппінгу квіток під упливом абіотичних чинників. Але у перехреснозапильних видів унаслідок дії інбредної депресії відбувається зниження урожайності нащадків, тому серед самофертильних зразків необхідно проводити жорсткий добір рослин з мінімальним зниженням урожайності [10]. Враховуючи великий попит на насіння люцерни посівної та його високу ціну, створення самофертильних сортів зі сталою урожайністю насіння $\epsilon$ актуальним.

Мета досліджень. Оцінка урожайності насіння та зеленої маси 26 нових самофертильних зразків люцерни посівної з рівнем самосумісності 38-52\%.

Матеріали і методи досліджень. Науково-дослідну роботу щодо вивчення селекційних зразків люцерни посівної проводили протягом двох років на полях лабораторії селекції виробничого підрозділу НУБіП України «Агрономічна дослідна станція» відповідно до робочої програми проведення досліджень по державній тематиці № 110/362-пр «Створити нові високоврожайні сорти і гібриди озимого жита, кукурудзи, люцерни, квасолі 3 високою технологічністю, адаптовані до біо- та абіотичних факторів довкілля».

Досліджували 26 нових самофертильних зразків люцерни посівної, створених нами протягом двадцяти років. Зразки мали різне географічне походження (Швеція, Франція, Канада, Україна). Спочатку вивчали рівень самосумісності при штучному самозапиленні рослин колекційних зразків протягом двох років, у подальшому добирали самофертильні рослини за низьким рівнем прояву дії інбредної депресії на врожайність насіння та зеленої маси у нащадків 6-8 поколінь самозапилення. Гібридизацію кращих за ознаками рослин проводили штучно, одержане насіння розмножували ізольовано та використовували для закладання розсадника попереднього сортовипробування.

Розсадник попереднього сортовипробування за врожайністю насіння закладений широкорядно, ширина міжрядь - 0,6 м, норма висіву насіння - 2 кг/га. Площа ділянки в розсадника - $10 \mathrm{M}^{2}$, повторність чотириразова. Для визначення врожайності кормової маси закладали окремий розсадник 
Оцінка нових самофертильних селекційних зразків люцерни посівної (Medicago sativa L.)

з рядковим посівом шириною міжрядь 15 см, нормою висіву - 15 кг/га. Площа ділянки $5 \mathrm{M}^{2}$. Повторність - триразова.

Догляд за посівами, збирання врожаю проводили відповідно до методики польових досліджень [11]. Зелену масу скошували, коли рослини знаходились у фазі бутонізації, тричі за сезон, зважування проводили безпосередньо на полі. Уміст сухої речовини визначали в лабораторних умовах методом висушування.

Математичний обробіток одержаних результатів проводився за допомогою програми «Статистика 6.0».

\section{Результати}

досліджень. Вивчення врожайності насіння селекційних зразків люцерни посівної показали, що 15 з 26 досліджуваних зразків (табл. 1) перевищили або були на рівні широковідомого першого українського самофертильного сорту-синтетика Ярославна. У середньому за два роки перевищення становило від 0,005 до 0,062 т/га або 2,2-27,2\%. Статистично достовірно вищу врожайність показали тільки три сортозразки: 36/10, 33/09 та 58/10 з перевищенням урожайності стандарту на 12,3 , 12,7 та 27,2\% відпровідно.

Таким чином, три нові зразки люцерни посівної з рівнем самофертильності 43,5, 46,7 та 53,4\% можуть бути включені в селекційний процес зі створення сортів 3 високою врожайністю насіння в умовах недостатньої кількості комах-запилювачів.

Для сортів кормових культур, якою $\epsilon$ люцерна посівна, основним показником $\epsilon$ врожайність зеленої маси та вихід сухої речовини. Тільки у шести 326 досліджуваних селекційних зразків урожай- ність зеленої маси була нижчою ніж у сорту-стандарту. Одинадцять зразків мали врожайність зеленої маси статистично вищу, ніж у сортустандарту Ярославна (табл. 2).

Перевищення врожайності коливалось від 0,6 до 4,5 т/га або від 1,2 до 7,1\%.

Встановлена від'ємна кореляція між урожайністю насіння та кормової маси у сортів

Таблиця 1

Урожайність насіння сортозразків люцерни

\begin{tabular}{|l|c|c|c|c|}
\hline \multirow{2}{*}{ Селекційні зразки } & \multicolumn{3}{|c|}{ Урожайність, т/га } & \multirow{2}{*}{ \% до } \\
\cline { 2 - 4 } & 2009 р. & 2010 р. & середнє & стандарту \\
\hline Ярославна - стандарт & 0,211 & 0,244 & 0,228 & 100,0 \\
\hline Добори із сорту Альфа & 0,220 & 0,235 & 0,228 & 100,0 \\
\hline Добори із сорту Меховська & 0,213 & 0,253 & 0,233 & 102,2 \\
\hline Добори із сорту Тетон & 0,227 & 0,229 & 0,228 & 100,0 \\
\hline Добори із сорту Унітро & 0,232 & 0,251 & 0,242 & 106,1 \\
\hline Добори із сорту Ромашка 9 & 0,240 & 0,260 & 0,250 & 109,6 \\
\hline Добори із сорту Чернігівська & 0,243 & 0,254 & 0,249 & 109,2 \\
\hline Добори із сорту Омега & 0,237 & 0,252 & 0,245 & 107,5 \\
\hline $58 / 10$ & $0,283^{*}$ & $0,297 *$ & $0,290^{*}$ & 127,2 \\
\hline $36 / 10$ & 0,242 & 0,270 & $0,256^{*}$ & 112,3 \\
\hline $43 / 09$ & 0,239 & 0,259 & 0,249 & 109,2 \\
\hline $52 / 10$ & 0,244 & 0,259 & 0,252 & 110,5 \\
\hline $33 / 09$ & $0,252^{*}$ & 0,261 & $0,257^{*}$ & 112,7 \\
\hline $89 / 09$ & $0,248^{*}$ & 0,243 & 0,246 & 107,9 \\
\hline $39 / 10$ & 0,238 & 0,263 & 0,251 & 110,1 \\
\hline НIP 0,5 & 0,035 & 0,029 & 0,028 & \\
\hline
\end{tabular}

* - достовірно при $\mathrm{p}=0,05$.

Урожайність зеленої маси сортозразків люцерни

\begin{tabular}{|c|c|c|c|c|}
\hline \multirow{2}{*}{ Селекційні сортозразки } & \multicolumn{3}{|c|}{ Урожайність, т/га } & \multirow{2}{*}{$\begin{array}{c}\text { \% до } \\
\text { стандарту }\end{array}$} \\
\hline & 2009 p. & 2010 p. & середнє & \\
\hline Ярославна - стандарт & 60,4 & 66,0 & 63,2 & 100 \\
\hline Добори із сорту Альфа & $62,7^{*}$ & $69,4^{*}$ & $66,1^{*}$ & 104,6 \\
\hline Добори із сорту Меховська & 62,3 & 67,1 & 64,7 & 102,4 \\
\hline Добори із сорту Тетон & 52,1 & 64,8 & 58,5 & 92,6 \\
\hline Добори із сорту Унітро & $63,6^{*}$ & $71,5^{*}$ & $67,6^{*}$ & 106,9 \\
\hline Добір із сорту Ромашка 9 & $64,5^{*}$ & 68,5 & $66,5^{*}$ & 105,2 \\
\hline Добори із сорту Чернігівська & $66,1^{*}$ & 64,9 & 65,5 & 103,6 \\
\hline Добори із сорту Омега & $65,3^{*}$ & 62,6 & 63,9 & 101,2 \\
\hline $58 / 10$ & 60,5 & 62,2 & 61,4 & 97,1 \\
\hline $36 / 10$ & $64,4^{*}$ & 66,2 & 65,3 & 103,3 \\
\hline $43 / 09$ & $66,0^{*}$ & $69,4^{*}$ & $67,7^{*}$ & 107,1 \\
\hline $52 / 10$ & $66,9 *$ & 65,1 & $66,0^{*}$ & 104,4 \\
\hline $33 / 09$ & 62,5 & $69,7^{*}$ & $66,1^{*}$ & 104,6 \\
\hline $89 / 09$ & $63,6^{*}$ & 67,7 & $65,7^{*}$ & 104,0 \\
\hline $39 / 10$ & $67,2^{*}$ & 63,5 & 65,4 & 103,4 \\
\hline HIP 0,5 & 2,3 & 3,1 & 2,4 & \\
\hline
\end{tabular}

* - достовірно при $\mathrm{p}=0,05$. 
люцерни посівної. Адже для розвитку генеративних органів рослини потрібним $\epsilon$ достатнє освітлення, а за наростання вегетативної маси нижні яруси гілок затінюються, китиці закладаються тільки на верхніх ярусах, що знижує врожайність насіння. Саме тому закладання насінницьких масивів рекомендується робити окремо, з малими нормами висіву (2-4 кг/га), широкорядно, 3 міжряддями не менше 0,45 м [12].

у дослідженнях селекційні зразки, які відзначались високою урожайністю насіння, урожайність зеленої маси мали на рівні сорту-стандарту Ярославна 3 перевищенням на 3,3-4,6\%, що $\in$ статистично недостовірним. Найвищу врожайність зеленої маси показали два зразки, які за три укоси сформували понад 67 т/га зеленої маси.

Вміст сухої речовини у досліджуваних зразках у середньому за два роки досліджень коливався від 22,1\% до 26,0\%, сорт-стандарт показав 23,9\% (табл. 3).

Враховуючи врожайність зеленої маси та вміст сухої речовини в ній, установили урожайність сухої речовини. У найурожайніших за зеленою масою селекційних зразків вихід сухої речовини становив 16,56 т/га та 16,59 т/га, у сорту-стандарту Ярославна - 15,10 т/га. У зразка з мінімальним умістом сухої речовини $22,1 \%$ урожайність сухої речовини становила
Таблиця 3

Урожайність сухої речовини (середнє за 2 роки), т/га

\begin{tabular}{|c|c|c|c|c|}
\hline \multirow[t]{2}{*}{ Селекційні зразки } & \multirow{2}{*}{$\begin{array}{c}\text { Вміст } \\
\text { сухої } \\
\text { речови- } \\
\text { ни, \% }\end{array}$} & \multicolumn{2}{|c|}{ Урожайність } & \multirow{2}{*}{$\begin{array}{c}\text { \% до } \\
\text { стандарту }\end{array}$} \\
\hline & & $\begin{array}{c}\text { зеленої } \\
\text { маси, т/га }\end{array}$ & $\begin{array}{c}\text { сухої } \\
\text { речови- } \\
\text { ни, т/га }\end{array}$ & \\
\hline Ярославна- стандарт & 23,9 & 63,2 & 15,1 & 100,0 \\
\hline Добори із сорту Альфа & 23,4 & $66,1^{*}$ & 15,5 & 102,6 \\
\hline Добори із сорту Меховська & 25,0 & 64,7 & $16,2^{*}$ & 107,3 \\
\hline Добори із сорту Тетон & 25,5 & 58,5 & 14,9 & 98,7 \\
\hline Добори із сорту Унітро & 24,5 & $67,6^{*}$ & $16,6^{*}$ & 109,9 \\
\hline Добір із сорту Ромашка 9 & 24,5 & $66,5^{\star}$ & $16,3^{*}$ & 107,9 \\
\hline Добори із сорту Чернігівська & 24,9 & 65,5 & $16,3^{*}$ & 107,9 \\
\hline Добори із сорту Омега & 24,4 & 63,9 & 15,6 & 103,3 \\
\hline $58 / 10$ & 24,6 & 61,4 & 15,1 & 100,0 \\
\hline $36 / 10$ & 23,9 & 65,3 & 15,6 & 103,3 \\
\hline $43 / 09$ & 24,5 & $67,7^{*}$ & $16,6^{*}$ & 109,9 \\
\hline $52 / 10$ & 22,1 & $66,0 *$ & 14,6 & 96,7 \\
\hline $33 / 09$ & 23,7 & $66,1^{*}$ & $15,7^{*}$ & 104,0 \\
\hline $89 / 09$ & 23,9 & $65,7^{*}$ & $15,7^{*}$ & 104,0 \\
\hline $39 / 10$ & 22,7 & 65,4 & 14,9 & 98,7 \\
\hline HIP 05 & & 2,4 & 0,6 & \\
\hline
\end{tabular}

* - достовірно при $\mathrm{p}=0,05$.

14,59 т/га, а у зразка з максимальним умістом $25,5 \%-14,92$ т/га.

Виходячи з одержаних результатів, у селекційному процесі зі створення високоврожайних сортів необхідно враховувати як урожайність зеленої маси, так і вміст сухої речовини в ній.

Висновки та рекомендації. Нові селекційні зразки люцерни посівної відзначались високими самофертильністю, врожайністю насіння на рівні 0,233-0,290 т/га за врожайності стандарту - 0,228 т/га. При цьому врожайність зеленої маси та сухої речовини цих зразків перевищувала врожайність стандарту або статистично недостовірно відрізнялась від неї.

В умовах недостатньої чисельності комах-запилювачів рекомендується господарствам усіх форм власності для забезпечення власних потреб у насінні цінної кормової багаторічної бобової трави - люцерни посівної, висівати самофертильні сорти, якими серед занесених до Реєстру сортів рослин, придатних для поширення в Україні на 2013 рік, є тільки Ярославна, Ольга, Роксолана та Віра. А у селекційному процесі зі створення високоврожайних сортів використовувати нові селекційні зразки 58/10, 36/10, 33/09.

\section{ВИКОРИСТАНА ЛІТЕРАТУРА}

1. Кормовиробництво: Навчальне видання - 2-е вид., доп. і перероб. - К.: Вища освіта, 2005. С. 152-169.

2. Ермакова Л.М. Роль люцерны посевной в биологизации растениеводства и сохранении почвенного плодородия в условиях Украины //
Генет. ресурсы культ. растений в XXI веке / Л.М. Ермакова, Р.Т. Ивановская, С.М. Каленская. ВИР, СПб. - 2007. - С. 69-76.

3. Жарінов В.І. Основні шляхи розвитку насінництва люцерни / В.I. Жарінов // Вісник с.-г. науки. 1980. - № 11. - C. 30-34. 
Оцінка нових самофертильних селекційних зразків люцерни посівної (Medicago sativa L.)

4. Писковацкий Ю.М. Пути повышения семенной продуктивности люцерны / Ю.М. Писковацкий // Селекция и семеноводство. - 1983. - № 9. - С. 15-17.

5. Благовещенская Н.Н. О строении и опылении цветка люцерны Medicago sativa L. / H.H. Благовещенская // Бот. журнал. - 1968. - Т. 53, № 9. - C. 1246-1253.

6. Busbice T.H. Effect of selection for self-fertility and self-sterility in alfalfa and related characters / T.H. Busbice, R.Y. Gurgis, H.B. Collins // Crop Sci. 1975.-V. 15, № 4. - P. 471-475.

7. Бобер А.Ф. Генетико-селекційні дослідження по створенню конкурентоздатних сортів автогамної люцерни / А.Ф. Бобер // Селекція та генетика на межі тисячоліть. - К.: Логос. - 2001. - Т. 3.C. 236-243.

8. Бобер А.Ф. Генетика аутогамии и селекция частично аутогамных популяций люцерны /
А.Ф. Бобер // V съезд ВОГиС им. Н.И. Вавилова. 1987. - T. IV, Ч. 1 - C. 48-51.

9. Башкірова Н.В. Самофертильність люцерни посівної як мутація гена несумісності та ії практичне значення / Н.В. Башкірова // Селекція та генетика на межі тисячоліть. - К.: Логос. 2001. - T.3 - C. 264-268.

10. Башкірова Н.В. Експериментальні зміни в системі розмноження люцерни посівної від алогамії до автогамії / Н.В. Башкірова, Т.В. Новак // Вісник Українського товариства генетиків і селекціонерів. - 2005. - Т. 3, № 1-2. - С. 21-25.

11. Доспехов Б.А. Методика полевого опыта / Б.А. Доспехов. - М. Агропромиздат. - 1985. $351 \mathrm{c}$.

12. Пыльнев В.В. Частная селекция полевых культур / В.В. Пыльнев, Ю.Б. Коновалов, Т.И. Хупарация и др. // М.: - Колос. - 2005. - С. 501-513

\section{ВИПРАВЛЕННЯ}

З різних причин у статті Костенко Н.П. і Стадніченко О.А. «Значення сортіветалонів для проведення кваліфікаційної експертизи», що вийшла друком у науково-практичному журналі «Сортовивчення та охорона прав на сорти рослин» № 4 (21) 2013 р., зі списку «Використана література» не надруковано першоджерело за № 12 під назвою «TPG/7/1 «Інструкція з використання документа UPOV щодо складання методик на ВОС-тест - К.: Алефа, 2005. - С. 33-34, 37-39.

Посилання на вищевказане джерело читати на ст. 65 , колонка 1 , кінець третього абзацу; с. 66 - колонка 3 після першого і другого абзаців та с. 67 - колонка 2, після третього абзацу.

На с. 64, колонка 1, у другому абзаці \pm . 